\title{
The Development of Social Infrastructure in Kazakhstan
}

\author{
Anar Yessengeldina \\ Abay Avenue 33a, 010000, Astana, Kazakhstan

\section{Diana Sitenko} \\ E.A. Buketov Karaganda State University \\ University street 28, Karaganda, Kazakhstan

\section{Anar Seitalinova} \\ Kazakh Academy of Engineering and Technology \\ Zheltoksan street 22a, Astana, Kazakhstan \\ doi:10.13165/VPA-14-13-2-03
}

The Academy of Public Administration under the President of the Republic of Kazakhstan

Abstract. The paper considers the content and significance of the social infrastructure in the Republic of Kazakhstan. The authors reveal the role of the Government in the formation and development of social infrastructure. The article provides the analysis of the current state of the social infrastructure of the Republic of Kazakhstan and identifies the main trends of its development. In the article, the situation and problems of development of the social infrastructure of different branches of industry are analyzed; trends and characteristics of their changes are identified. Practical recommendations aimed at improvement of the efficiency of the social infrastructure development in the modern world are developed.

Keywords: social infrastructure, social policy, education, health care, the Republic of Kazakhstan.

JEL classification: $H 70$ 


\section{Introduction}

Today there are complex and profound changes in the world economic system. The social sphere is a major subsystem of the economy and one of the main indicators of significant changes taking place in the society.

The study of the social sphere as a complex of infrastructure branches, providing a favorable human activity, all-round development of the individual, the extended form of human and labor resources of society, determined by the importance of the subsystem for a modern economy and the need to rethink the changes that it has undergone.

Therefore, at the present stage of the transformation of the economy of Kazakhstan, one of the most relevant problems is the condition and development of the social infrastructure, the development of which has been problematic because of the limited and, in some cases, an acute shortage of sources of development. It's a really urgent problem especially because the experience of developed countries shows that the progress of those states depends on the ability of their economies to adjust to the changes, which depend on the state and non-material forms of wealth, as well as areas that provide human development.

The problem of social infrastructure development has been the focus of many economists and each of them has studied a certain aspect of it. Different types and classifications of social infrastructure projects have been provided by some studies: Flora and Flora (1993) [7], Argy et al. (1999) [2], Sharp et al. (2002) [11]. At the same time, Flora and Flora (1993) [7], Dacin et al. (2010) [5], Westlund and Bolton (2003) [15] focused on the role of entrepreneurship in social infrastructure. English (2005) [6], Jefferies and McGeorge (2009) [8] connected social infrastructure development with public-private partnership mechanism. Most researches (Van de Ven (1993) [14], Aghion and Schankerman (1999) [1], Westlund and Bolton (2003) [16]) outline the importance of social infrastructure development on different levels.

In Kazakhstan, the problem of social infrastructure development was considered in the studies of Ashimbayeva (2000) [3], Mukhametzhanova (2001) [10], Smirnova (2004) [12], Yessengeldin et al. (2013) [17].

Assessing the studies of foreign and local scholars, it can be observed that some aspects of the development of social infrastructure in market conditions have not been understood well and they still remain controversial.

The cause is not only in a variety of approaches to the issue studied, dynamic and incomplete market reforms in the Republic of Kazakhstan, but also the emergence of new factors, which demand the complex study.

\section{Materials and methods}

The research methodology is based on the dialectical and system analysis, which is based on empirical (observation, comparison) and theoretical (analysis, synthesis) approaches. Furthermore, taking into account the heterogeneity of studied 
elements of the development of social infrastructure, as well as differences in the objectives of financial and economic activity of the market, synergistic method of summarizing the results of the work from the point of view of the interdependence of social and economic processes in society, as well as the institutional approach have been used.

The article is based on data of the Agency on Statistics of the Republic of Kazakhstan, the legislative and regulatory framework for social welfare, education and health, program documents of the Government of the Republic of Kazakhstan.

\section{The main part}

Social infrastructure is characterized by features of settlement, production and labor, the economic mechanism, its formation and operation, and other properties as a social and territorial subsystem of society.

According to statistics, in 2012 the share of urban population in the Republic of Kazakhstan was $54.7 \%$, whereas the share of rural population reached $45.3 \%$ [9] (Table 1).

Table 1. Population in the Republic of Kazakhstan, thousands and \%

\begin{tabular}{|c|c|c|c|c|c|}
\hline \multirow{2}{*}{ Year } & \multirow{2}{*}{$\begin{array}{c}\text { Total } \\
\text { population, } \\
\text { thousands }\end{array}$} & \multicolumn{2}{|c|}{ Include } & \multicolumn{2}{c|}{$\begin{array}{c}\text { In percent to total } \\
\text { population }\end{array}$} \\
\cline { 3 - 6 } & urban & rural & urban & rural \\
\hline $\mathbf{2 0 0 8}$ & 15571.5 & 8265.9 & 7305.6 & 53.1 & 46.9 \\
\hline $\mathbf{2 0 0 9}$ & 15982.4 & 8662.9 & 7319.5 & 54.3 & 45.7 \\
\hline $\mathbf{2 0 1 0}$ & 16203.0 & 8819.4 & 7383.6 & 54.4 & 45.6 \\
\hline $\mathbf{2 0 1 1}$ & 16440.1 & 8973.4 & 7466.7 & 54.6 & 45.4 \\
\hline $\mathbf{2 0 1 2}$ & 16673.1 & 9127.1 & 7546.0 & 54.7 & 45.3 \\
\hline
\end{tabular}

Source: Compiled by the authors based on the data of the Agency on Statistics of the Republic of Kazakhstan: Men and Women of Kazakhstan (2013) [9].

Social infrastructure by the type of settlements is divided into urban and rural infrastructure. The distinctive features of the rural social infrastructure are the following ones: the structure of objects; links of objects providing daily and periodic demand services (mixed trading shops, cafeterias, kindergartens, public schools, clubs and places of consumer services). The urban infrastructure is characterized by the presence of urban enterprises and institutions episodic demand, cultural and medical centers, transport companies, universities, banking, insurance, legal, notarial institutions, etc.

Meanwhile, there is a significant differentiation of incomes in urban and rural areas. In 2011, the poverty rate in rural areas exceeded the level of the urban ones by more than 3.7 times, though in 2007 the difference was only 2.6 times. This suggests 
the increase of quality of life indicators of urban residents in comparison with the rural population, despite the measures taken by the Government. It is important to note that the Kazakh village has about $45.3 \%$ of the population, so the fight against poverty is able to substantially improve quality indicators of life in the country.

Social infrastructure is characterized by an insufficient availability of rural population with basic non-productive assets and servicing enterprises (institutions), the worst quality composition of material, technical and human resources, high proportion of facilities located in the old and dilapidated buildings, the low level of technical equipment, the level of general education and professional training of the social sphere, which affects the quality of public services, including services on a fee basis. Also, social infrastructure in rural areas demands more time to obtain services in comparison with the urban one.

However, the financing of the social infrastructure of the state budget remains a top priority, evidenced by the data in Table 2 [13].

Table 2. The state budget financing of social infrastructure in the Republic of Kazakhstan, billion tenge and \%

\begin{tabular}{|c|c|c|c|c|c|}
\hline Types of expenditures & 2008 & 2009 & 2010 & 2011 & 2012 \\
\hline $\begin{array}{l}\text { Total state budget } \\
\text { expenditures, bln. tg., } \\
\text { include: }\end{array}$ & 3394.1 & 3746.8 & 4457.2 & 5423.2 & 6268.9 \\
\hline \multicolumn{6}{|l|}{ Education } \\
\hline Expenditures, bln. tg. & 572.4 & 660.9 & 755.3 & 986.8 & 1210.1 \\
\hline $\begin{array}{l}\text { In percent to total budget } \\
\text { expenditures }\end{array}$ & 16.9 & 17.6 & 16.9 & 18.2 & 19.3 \\
\hline \multicolumn{6}{|l|}{ Health care } \\
\hline Expenditures, bln. tg. & 363.2 & 450.9 & 551.3 & 626.3 & 730.8 \\
\hline $\begin{array}{l}\text { In percent to total budget } \\
\text { expenditures }\end{array}$ & 10.7 & 12.0 & 12.4 & 11.5 & 11.7 \\
\hline \multicolumn{6}{|l|}{ Social security and social aid } \\
\hline Expenditures, bln. tg. & 622.0 & 758.3 & 905.3 & 1133.6 & 1239.0 \\
\hline $\begin{array}{l}\text { In percent to total budget } \\
\text { expenditures }\end{array}$ & 18.3 & 20.2 & 20.3 & 20.9 & 19.8 \\
\hline \multicolumn{6}{|c|}{ Housing and communal services } \\
\hline Expenditures, bln. tg. & 233.9 & 304.1 & 334.2 & 389.2 & 738.6 \\
\hline $\begin{array}{l}\text { In percent to total budget } \\
\text { expenditures }\end{array}$ & 6.9 & 8.1 & 7.5 & 7.2 & 11.8 \\
\hline
\end{tabular}

Source: Compiled by the authors based on the data of the Statistical Bulletin on the Budget of the Republic of Kazakhstan (2013) [13]. 
An important indicator of the formation of a new quality of human capital is the education of population. In this regard, Kazakhstan has achieved a high level of development. Currently, the population of Kazakhstan has the educational level of $99.7 \%$. These achievements are largely due to the fact that the expenditures of the state budget for education are quite high; in 2012, the figure was $19.3 \%$ of the total state budget expenditures in Kazakhstan.

Health care spending over the last five years consumed an average of 10-12 percent of the total state budget expenditures. Health expenditure per capita for this period increased. The health status of the population as an indicator of social wellbeing of the society depends not only on the level of resources and the health and social security ( $20 \%$ of the expenditures of the state budget) in the country, but also on other factors, such as a healthy lifestyle, living environment, etc.

In 2012, there was a sharp increase in the cost of housing and communal services (from $7.2 \%$ in 2011 to $11.8 \%$ in 2012). All the country's housing at the beginning of 2012 amounted to 283.9 million square meters, of which 167.3 million square meters, or $58.9 \%$, are located in cities and other urban areas, and 116.6 million square meters $(41.1 \%)$ in rural areas. At the same time, nearly all housing $(96.3 \%)$ is now in private ownership and only $3.7 \%$ (10.3 million square meters) remained as the state property [4].

Despite of the significant growth of the construction of new housing units over the past 6-7 years, the availability of housing for the population of the country continues to be a rather serious problem. Many families try to improve their living conditions and buy their own homes in the cities, where they moved in the last decade from the remote rural areas.

In addition, the characteristics of the social infrastructure are the territorial differences in the level of social investment, particularly natural and mechanical movement of the population, placing the potential of social infrastructure, inadequate resettlement, dispersed of objects, poor road communications, rise of the construction and operating costs, capital intensity and the costs of infrastructure operation according to the number of the population, and greater employment in the service sector compared with areas of compact residence (at the same level of service).

The transition to a market economy has led to a fundamental change in social policy of the country, the commercialization of the agrarian sector, exacerbated conflicts and reduced the quality and standard of living. Market of social goods and services got uncivilized nature, leading to social inequality of the most vulnerable social groups. Therefore, the reform of the social infrastructure requires a comprehensive approach, providing for the development of multiculturalism not only in production, but also in the social sphere.

Sustainable development of the social infrastructure depends on the study of the economic laws of social development, social processes and the specific conditions of living of the population. The main role in the use of these laws belongs to a 
coherent system of principles, methods, forms and means of social infrastructure as the specific tools of scientific and practical knowledge and action. The social infrastructure from a scientific point of view can be seen in two ways: 1) the theoretical and methodological, fundamental way, which studies the methodology, considers the laws, principles and categorical apparatus, and 2) social and practical, managerial application of theoretical and empirical knowledge to the solution of practical social problems.

Theoretical, methodological and practical bases of the mechanism for sustainable development of the social infrastructure of the country are based on a system of science-based and coordinated social, economic, institutional, managerial, organizational and ethical aspects of decisions that have an impact in terms of economic interests, which allow formulating the concept of sustainable development mechanism social infrastructure (Figure 1).

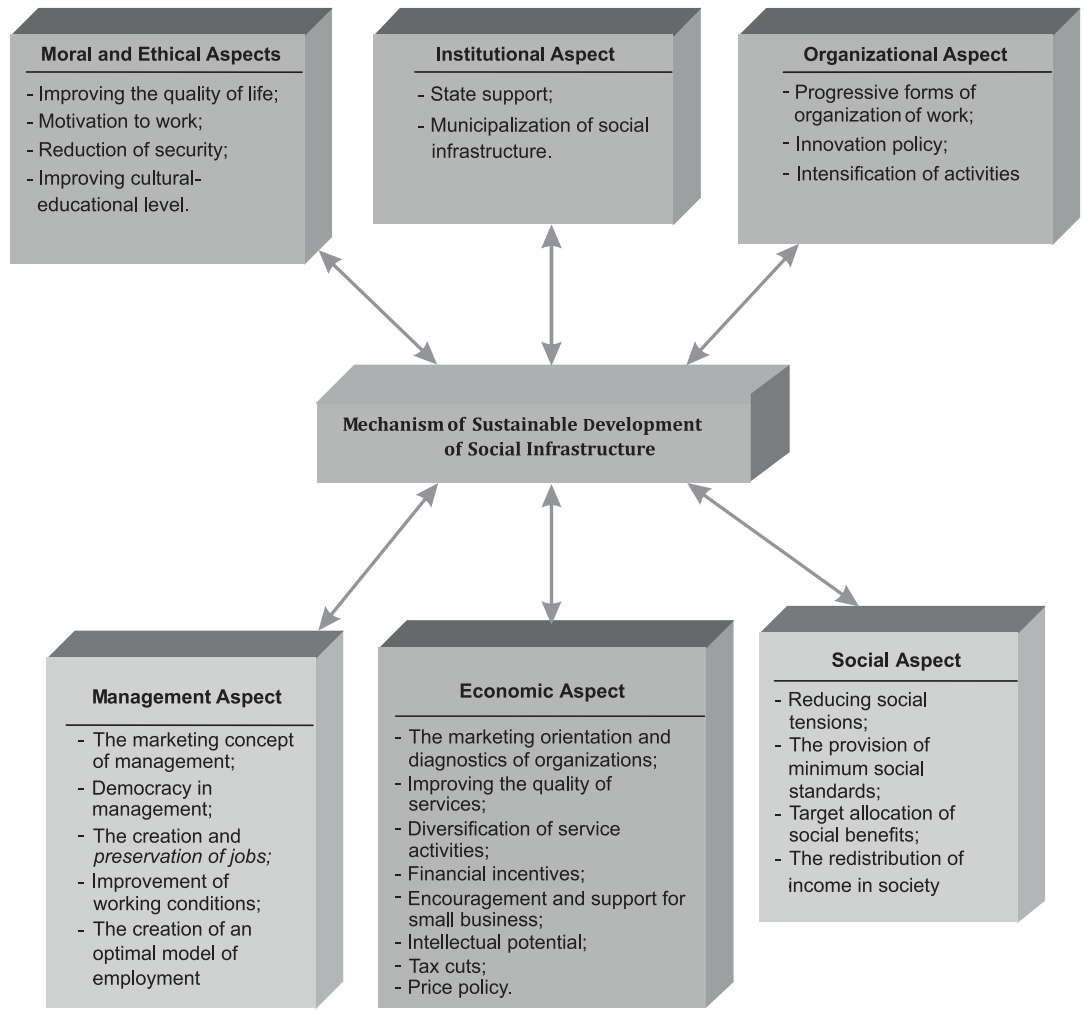

Figure 1. Mechanism of sustainable development of social infrastructure 
In the narrow sense, the mechanism for sustainable development of the social infrastructure is certain system actions for sustainable and balanced functioning of the social infrastructure aimed at improving the welfare of the population.

In the broad sense, the mechanism for sustainable development of the social infrastructure is a set of methods, activities, performance, incentives, which impacts on certain socio-economic, institutional, administrative, organizational and ethical processes in the area of social infrastructure in order to increase its effectiveness.

Thus, the authors conclude that a sustainable, science-based system of social infrastructure is designed to integrate social connections and relationships, form new social communities, ensure the implementation of social needs. Such system will provide the necessary guarantees of decent standard of living of citizens in compliance with the most important principles - the unity of economic efficiency and social justice, the symbiotic relationship of protection and self-defense of subsidiarity.

\section{Conclusion}

The main trends in the development of the social infrastructure of Kazakhstan in the current conditions are characterized by the following features:

- the lack of an effective concept of development of the country, i.e., waiver from strict definitions set by the state and guarantee services; denationalization of social infrastructure and getting rid of the functions of the state monopoly producer of social benefits, the diversification of social infrastructure by the type of ownership, the transition from a categorical social assistance to a direct one; regionalization of social policy, etc., because of its extreme inefficiency;

- the reduction in technical, scientific and intellectual potential, i.e., enterprises and institutions of social infrastructure functioning under the new economic conditions have not kept their production, human and scientific potential, as this sphere is in a slow process of development of modern logistics and manufacturing facilities in existing enterprises, the introduction of efficient technologies, the competitiveness of services modernization of social infrastructure, the introduction of new forms of cooperation and integration;

- low investment and entrepreneurial activity in the social sphere, lack of own financial resources, which are the main source of production and upgrade technical base of the social infrastructure, a limiting factor in their investment and entrepreneurial activity.

The Government, accumulating and redistributing funds, has the ability to initiate action through the legislative process in the development of positive social area of the village, designed to disintegration, support competitive relations of interaction between different social structures, the development of social life, ways of life, the promotion of economic activity in this area as local municipalities and private businesses. 
The republican target programs for electrification, water supply and gasification of the village, the road construction, the development of communication, broadcasting and television are the mechanisms for the development of social infrastructure. Their implementation will allow the formation of needed habitat and livelihoods for goods producers, the formation of the system of settlement, restoration, development and maintenance of the social engineering infrastructure.

Commercial social structures face the lack of adequate legal framework, organizational difficulties, the lack of measures of small businesses support, the imperfection of the tax system, instability and uncertainty, the lack of interest of private capital in the production of social services, because often benefits from their creation can be received by third parties without incurring any costs of production.

Improvement of the efficiency of the social infrastructure development in rural areas requires a reform of their organizational, administrative and economic mechanisms, since the old system was designed for public funding and provision of control over the allocation of public fund. Strict and detailed centralization of various aspects of economic activity of the organizations of social infrastructure, shortage of many raw materials, equipment and components, dictate of the supplier under the consumer, lack of real possibilities of modernization and development of own production do not ensure the independence of the organizations to use marketing tools.

The revealed problems and trends point at the poor functioning of social infrastructure and demonstrate the need for immediate action, having an integrated program approach and aimed at intensifying the development of a network of social infrastructure, improve the quality and standard of living, poverty reduction, targeted use of labor resources, the creation and preservation of jobs, incentives for social workers.

\section{Results}

When examined the problems and peculiarities of social infrastructure, in the authors' opinion, further development of social infrastructure needs to take the following measures:

- inclusion of social sphere into market relations in order to achieve socioeconomic balance between urban and rural areas;

- priority of state support for social services;

- provision of agricultural enterprises, containing objects of social sphere with guarantees, benefits in product sales, credit resources, incentives;

- tax reduction (including land tax) for agricultural enterprises, in proportion to the costs of the remaining objects;

- provision of benefits and compensation for professionals working in sociocultural sectors. 


\section{References}

1. Aghion, P.; Schankerman, M. Competition, Entry and the Social Returns to Infrastructure in Transition Economies. Economics of Transition. 1999, 7(1): 79-101.

2. Argy, F.; Lindfield, M.; Stimson, B.; Hollingsworth, P. Infrastructure and Economic Development. CEDA Information Paper No. 60. Committee for Economic Development of Australia. Melbourne, 1999.

3. Ashimbaeva, A. T. Economic Structure: Mechanisms of Formation, Development Trends and Priorities. Almaty, 2000.

4. Aygazin, J. J.; Tulenov, T. B. Analysis of the Indicators Characterizing the Quality of Life of Population in the Republic of Kazakhstan. Astana: Private Institution Research Center for Applied Economics, 2012.

5. Dacin, P. A.; Dacin, M. T.; Matear, M. Social Entrepreneurship: Why We Don't Need a New Theory and How We Move Forward from Here. The Academy of Management Perspectives. 2010, 24(3): 37-57.

6. English, L. M. Using Public-Private Partnerships to Deliver Social Infrastructure: The Australian Experience. The Challenge of Public-Private Partnerships: Learning from International Experience. 2005, p. 290.

7. Flora, C. B.; Flora, J. L. Entrepreneurial Social Infrastructure: A Necessary Ingredient. The Annals of the American Academy of Political and Social Science. 1993, 529(1): 48-58.

8. Jefferies, M.; McGeorge, W. D. Using Public-Private Partnerships (PPPs) to Procure Social Infrastructure in Australia. Engineering, Construction and Architectural Management. 2009, 16(5): 415-437.

9. Men and Women of Kazakhstan. Statistical Book. Astana, 2013.

10. Mukhamedzhanova, A. G. The Human Capital of Kazakhstan: Formation, Present Situation and Using. Almaty: Gylym, 2001.

11. Sharp, J. S., et al. Social Infrastructure and Community Economic Development Strategies: The Case of Self-Development and Industrial Recruitment in Rural Iowa. Journal of Rural Studies. 2002, 18(4): 405-417.

12. Smirnova, T. P. The Institutional Approach to the Study of Problems of Social Infrastructure. Almaty: Economics, 2004.

13. Statistical Bulletin on the Budget of the Republic of Kazakhstan. Astana, 2013.

14. Van de Ven, H. The Development of an Infrastructure for Entrepreneurship. Journal of Business Venturing. 1993, 8(3): 211-230.

15. Westlund, H.; Bolton, R. Local Social Capital and Entrepreneurship. Small Business Economics. 2003, 21(2): 77-113.

16. Westlund, H.; Bolton, R. Local Social Capital and Entrepreneurship. Small Business Economics. 2003, 21(2): 77-112.

17. Yessengeldin, B.; Biryukov, V.; Sitenko, D. Potential of Education as a Factor of Human Capital Development. Actual Problems of Economics. 2013, 3: 267-274. 


\section{Anar Yessengeldina, Diana Sitenko, Anar Seitalinova \\ Socialinės infrastruktūros plètra Kazachstane}

\section{Anotacija}

Straipsnyje apžvelgiama Kazachstano Respublikos socialinès infrastruktūros turinys ir svarba. Autoriai atskleidžia vyriausybès vaidmenį formuojant ir vystant socialinę infrastruktūrą. Straipsnyje atlikta dabartinès Kazachstano Respublikos socialinès infrastruktūros būklès analizè ir ịvardijamos pagrindinès socialinès infrastruktūros plètros tendencijos. Išnagrinètos socialinès infrastruktūros plètros sąlygos ir problemos ịvairiose pramonės šakose, nustatytos pokyčių kryptys ir ypatumai. Pasiūlytos socialinès infrastruktūros plètros efektyvumo gerinimo šiuolaikiniame pasaulyje praktinès rekomendacijos.

Anar Yessengeldina - Viešojo administravimo akademijos prie Kazachstano Respublikos Prezidento Valstybinio ir vietos administravimo katedros docenté, ekonomikos mokslų kandidaté. El.paštas: yanar77@inbox.ru

Diana Sitenko - Karagandos E. A. Buketovo valstybinio universiteto docente, ekonomikos mokslų daktarè.

El. paštas: 2daesha@list.ru

Anar Seitalinova - Kazachstano inžinerijos ir technologijų akademijos docentė, ekonomikos mokslų kandidatè.

El. paštas: anara_ss73@mail.ru

Anar Yessengeldina, Candidate of Economic Science, Academy of Public Administration under the President of the Republic of Kazakhstan, Department of Public and Local Administration, Associate Professor.

E-mail: yanar77@inbox.ru

Diana Sitenko, PhD in Economics, E.A. Buketov Karaganda State University, Senior lecturer. E-mail: 2daesha@list.ru

Anar Seitalinova, Candidate of Economic Science, Kazakh Academy of Engineering and Technology, Associate Professor.

E-mail: anara_ss73@mail.ru

Straipsnis ịteiktas redakcijai $2014 \mathrm{~m}$. kovo 5 d.; recenzuotas; parengtas spaudai $2014 \mathrm{~m}$. gegužès $28 \mathrm{~d}$. 